\title{
MICROCRYSTALLINE CELLULOSE REINFORCED CHITOSAN COATING ON KRAFT PAPER
}

\author{
TAWHIDA AKTER, ${ }^{*}$ JANNATUN NAYEEM, $^{*}$ ARIFUL HAI QUADERY, ${ }^{* *}$ \\ M. ABDUR RAZZAQ, ${ }^{* *}$ M. TUSHAR UDDIN, ${ }^{* * *}$ M. SHAHRIAR BASHAR ${ }^{* * *}$ and \\ M. SARWAR JAHAN* \\ "Pulp and Paper Research Division, BCSIR Laboratories, Dhaka 1205, Bangladesh \\ ${ }^{* *}$ Leather Research Institute, BCSIR Nayarhat, Savar, Dhaka, Bangladesh \\ ${ }^{* * * *}$ IFRD, BCSIR, Dhaka, Bangladesh \\ $\square$ Corresponding author: M. Sarwar Jahan, sarwar2065@yahoo.co.uk
}

Received May 30, 2019

Paper is widely used in the packaging sector. Water vapor barrier and water resistance properties of packaging paper need to be improved by changing the wettability of its surface with sizing agents or through coating with hydrophobic materials, such as paraffin wax, polyethylene, poly(ethylene terephthalate) and poly(butylene terephthalate). In this study, a biodegradable coating was applied on kraft paper. The application of chitosan as a coating on kraft paper sheets could be an alternative to commercial synthetic polymer coatings.

Chitosan with microcrystalline cellulose (MCC) was used to coat kraft paper sheets. The different concentration of chitosan and MCC were evaluated. The application of $1 \%$ chitosan $\left(4.7 \mathrm{~g} / \mathrm{m}^{2}\right)$ alone lowered the water vapour permeability rate (WVTR) by $41.1 \%$, the water absorption capacity (Cobb test) by $54.9 \%$, while porosity decreased twice. An increase in chitosan concentration further improved these properties significantly. The addition of $1 \% \mathrm{MCC}$ to $1 \%$ chitosan further reduced WVTR, porosity and $\mathrm{Cobb}_{60}$ value. Also, a slight increase in the papermaking properties of coated paper was observed. MCC added to the chitosan coating increased the gloss value of the coated paper sheet. The addition of protein from leather mill wastes to the chitosan coating, instead of MCC, also improved these properties. However, coating both sides of the paper did not have the same effect.

Keywords: paper coating, chitosan, MCC, protein, barrier properties, opacity

\section{INTRODUCTION}

Plastic is widely used in food packaging materials due to its good barrier properties. However, it creates environmental problems and hampers the recycling of plastic coated paper. Therefore, biopolymer-based packaging materials, originating from naturally renewable resources, such as polysaccharides, proteins and lipids, or combinations of those components, have attracted substantial interest in terms of both laboratory research and industrial applications. ${ }^{1-4}$ Food packaging materials based on paper need functionality under permanently changing conditions in the surrounding environment, such as temperature, storage time, or moisture, which exert major influence on the shelf-life and quality of the packed food. ${ }^{5-7}$

Proteins, polysaccharides and lipids are the three main green-based materials, which are often used to coat paper surface via filming for packaging application. Coating with proteins and/or polysaccharides possesses excellent mechanical properties and resistance to oxygen, nitrogen and carbon dioxide due to the presence of inter-/intramolecular hydrogen bonding. ${ }^{8-10}$

In the rapid development of paper coating, chitosan has been widely studied for improving mechanical and barrier properties towards gas, moisture and fat. ${ }^{11-12}$ The required properties of paper depend on its application; for example, some food packaging applications require high permeability of oxygen or even low water permeability; on the other hand, paper for fried potatoes package has to be oil-impermeable. The barrier and mechanical properties of paper can be modified by coating using a non-renewable polymer. Kjellgren et al. ${ }^{13}$ showed that chitosan coated paper at the laboratory and pilot scale had 
oxygen permeability in the same range as that of poly(ethylene terephthalate) and was obtained at coat weights exceeding $5 \mathrm{~g} / \mathrm{m}^{2}$. Chitosan increased the elongation at break $(\% \mathrm{E})$ of coated paper, as shown by Khwaldia et al. ${ }^{14}$ The application of chitosan as a second layer on wet or dry caseinate films reduced paper WVP. Zhang et $a l .{ }^{12}$ investigated bilayer coating, performed by two separate coating procedures, using various combinations of proteins or polysaccharides with beewax, in order to overcome the deficiencies of single layer coating. Among these combinations, chitosan-beewax bilayer coated paper showed the best water vapour barrier property. It was observed that, as the concentration of the chitosan solution increased from 1.0 to $3.0 \mathrm{wt} \%$, its water vapour transport rate (WVTR) decreased from 171.6 to $52.8 \mathrm{~g} / \mathrm{m}^{2} / \mathrm{d}$. Cellulose nanofibers with carboxymethyl cellulose produced homogeneous coating on the surface of paper and led to a distinct improvement in its barrier properties. ${ }^{15}$

Whey protein has been also studied in coating application on paper. ${ }^{8}$ A substantial amount of leather shavings are generated in the leather industry in Bangladesh, which is a potential source of protein. Recently, a process has been developed to isolate protein from leather shavings. In this study, protein isolated from leather shaving was used for paper coating with a chitosan solution. To the best of our knowledge, no study has been reported on coating paper with chitosan and protein isolated from leather shavings produced in Bangladesh.

The aim of this work has been to apply chitosan coating on paper produced by Kharnaphuli Paper Mills (KPM) from Bangladesh. Chitosan was mixed with microcrystalline cellulose (MCC) in different proportion and used in coating. Then, the surface, barrier, optical and physical properties of coated paper were evaluated.

\section{EXPERIMENTAL \\ Materials}

Paper sheets of 70 GSM were collected from KPM (Bangladesh), which was produced from bamboo and mixed hardwood kraft pulp. Chitosan was prepared in our laboratory using a method described elsewhere. ${ }^{16}$ MCC was extracted from jute fiber using sulfuric acid hydrolysis. ${ }^{17}$ Protein was prepared from leather shaving dust by enzymatic hydrolysis and was received from the Leather Research Institute, Nayarhat, Savar, Dhaka.

\section{Preparation of chitosan coating solutions}

The chitosan coating solution was prepared by dissolving 1, 2 and $3 \mathrm{~g}$ chitosan in $100 \mathrm{~mL}$ of $1 \%$ acetic acid, under constant stirring for $6 \mathrm{~h}$ at $400 \mathrm{rpm}$. The MCC-chitosan solution was prepared by dispersing different amounts $(\mathrm{g} / \mathrm{v})$ of $\mathrm{MCC}$ in the chitosan solution in homogenizer for $10 \mathrm{~min}$ at 15000 rpm.

\section{Coating method}

The chitosan solution was applied to the surface of paper with an RK Control K303 laboratory coater. The drying of the coated samples was performed in an aircirculation laboratory oven at $105{ }^{\circ} \mathrm{C}$. Two different coating levels were applied (on one and both sides of the paper) with a Mayer bar no. 3 (RK Print Coat Instruments, Ltd., Litlington, United Kingdom), with drying for $1 \mathrm{~min}$ after every layer. The speed of the coating bar was $2 \mathrm{~m} / \mathrm{min}$. The dried samples were conditioned and stored for at least 1 week in a climate room at $23{ }^{\circ} \mathrm{C}$ and $50 \%$ relative humidity (RH) before testing.

\section{Barrier properties}

The air permeability was measured according to ISO 5636/3:1992. The water vapor transmission rate (WVTR) was determined gravimetrically by a modified ASTM E-96A procedure, using SATRA equipment (model STM 172, UK). Anhydrous calcium chloride (Damp Rid, Orlando, FL) was used as desiccant and placed on the bottom of a circular aluminum dish, which had an inner mouth diameter of $8 \mathrm{~cm}$ and an inside depth of $2.2 \mathrm{~cm}$. The samples were cut and mounted on the mouth area of the dish-coated side toward high RH.

\section{Optical properties}

Brightness and opacity were measured using A Photovolt 577 reflectance meter, according to TAPPI T 452 om-98 and TAPPI T 425, respectively. The gloss of chitosan-coated paper sheets was measured with a BYK Garner GmbH gloss meter (USA). The gloss was measured on five different spots.

\section{Physical properties}

The tensile (T 494 om-96), tear (T 414 om-98) and burst index (T 403 om-97) of blank (non-coated), single and both sides coated papers were determined according to Tappi Standard Methods.

\section{Scanning electron microscopy (SEM)}

The surface morphology of the papers was examined by scanning electron microscopy (SEM), using a FEI Quanta 200 microscope. The samples were gold sputtered using a Sputta Coater S150 under vacuum. SEM was carried out to give further insight on the homogeneity of the coatings. All the samples were examined using an accelerating voltage of $20 \mathrm{kV}$. 


\section{RESULTS AND DISCUSSION}

High-molecular-weight chitosan formed viscous solutions, as shown in Table 1. The viscosity of $1 \%$ chitosan solution was $218 \mathrm{mPa} \mathrm{s}$, which increased to $598 \mathrm{mPa}$.s for the $2 \%$ chitosan solution. The addition of MCC to the $2 \%$ chitosan solution increased viscosity. The addition of protein reduced the viscosity of the coating solutions. All the solutions were easy to apply onto the paper using a laboratory coater. The coatings were even and homogeneous without any bubbles or defects.

\section{Surface properties}

Table 2 shows the coated chitosan concentration and microcrystalline cellulose (MCC) concentration and the respective coating weights. The weight of the chitosan coat was at least $4.7 \mathrm{~g} / \mathrm{m}^{2}$ for $1 \%$ chitosan concentration, which further increased with increasing the MCC addition to the coating solution. SEM images of the uncoated and coated paper with $1.0 \%$ chitosan, $1 \%$ chitosan- $1 \% \mathrm{MCC}$ and $1 \%$ chitosanprotein are shown in Figure 1. The chitosan coating did not form a uniform film on the paper surface. The diluted solution penetrates into the voids of the paper, while chitosan simultaneously covers the fibers since cellulose and chitosan are chemically attracted due to hydrogen bonding. The surface of the fibers in the chitosan coated samples is smooth and clean. Similar observations regarding chitosan coating have been made by other researchers. ${ }^{3,10}$ Compared to uncoated paper, the paper coated by chitosan has a smoother surface, due to the good film formation property of chitosan. It was also found that the application of even a small amount of chitosan solution showed good coverage. ${ }^{18}$

Table 2 shows the Gurley air resistance of base papers coated on a bench scale. The air resistance increased for $1 \%$ chitosan coating, and then further increased sharply with the addition of MCC. MCC sealed the surface pores in the base paper and a continuous chitosan film could be developed. Higher coat weight can affect paper properties, especially the barrier properties, and thus is not necessary provided that full coverage is achieved. Lower porosity of the paper coated with chitosan and MCC indicated that the pinholes or voids present in the coated paper were reduced. ${ }^{19}$

Figure 2 shows a decrease in the water absorption value of the paper coated with chitosan. The $\mathrm{Cobb}_{60}$ value for the uncoated paper was $69 \mathrm{~g} / \mathrm{m}^{2}$. Papers coated with $1 \%$ chitosan were able to absorb only $45 \%$ water for $60 \mathrm{~s}$, which was further reduced to $37 \%$ with increasing chitosan to $2 \%$. The addition of MCC to the chitosan solution slightly reduced the drop of water absorption. This can be explained by the fact that MCC is a hydrophilic material, and therefore introducing it into paper coating did not significantly reduce the water uptake. On the other hand, the positively charged chitosan used for coating both substrates interacted very intensively with the negatively charged cellulosic fibers. The chitosan solution used for coating is only water-soluble in the presence of acetic acid at $\mathrm{pH}$ 4. Above this $\mathrm{pH}$, chitosan is not watersoluble, and can be considered as "hydrophobic". ${ }^{12}$ However, both sides coating did not further improve the $\mathrm{Cobb}_{60}$ value (Table 3 ).

Table 1

Viscosity of chitosan solution at $20{ }^{\circ} \mathrm{C}$

\begin{tabular}{lc}
\hline Chitosan solution & Viscosity (mPa.s) \\
\hline $1 \%$ chitosan & 218 \\
$2 \%$ chitosan & 598 \\
$1 \%$ Chitosan+ 1\% MCC & 211 \\
$1 \%$ Chitosan+ 2\% MCC & 203 \\
$1 \%$ Chitosan+ 3\% MCC & 209 \\
$2 \%$ Chitosan+ 1\% MCC & 634 \\
$2 \%$ Chitosan+ 2\% MCC & 718 \\
$2 \%$ Chitosan+ 3\% MCC & 730 \\
$1 \%$ Chitosan+ 49.3\% protein (1:1) & 158 \\
\hline
\end{tabular}


Table 2

Coat weight and porosity chitosan coating

\begin{tabular}{ccccc}
\hline Sr No & Chitosan $(\%)$ & MCC $(\%)$ & Coat weight $\left(\mathrm{g} / \mathrm{m}^{2}\right)$ & Porosity $(\mathrm{s} / 50 \mathrm{~mL})$ \\
\hline 1 & 0 & 0 & - & 8 \\
2 & 1 & 0 & 4.7 & 16 \\
3 & 1 & 1 & 4.9 & 70 \\
4 & 1 & 2 & 5.6 & 89 \\
5 & 1 & 3 & 5.5 & 130 \\
6 & 2 & 0 & 5.2 & 37.5 \\
7 & 2 & 1 & 8.5 & 84 \\
8 & 2 & 2 & 8.8 & 78 \\
9 & 3 & 0 & 7.1 & 72 \\
$10^{*}$ & 1 & 0 & 7.5 & \\
\hline
\end{tabular}

$* 1: 1$ Protein solution $(49.3 \%)$ and $1 \%$ chitosan
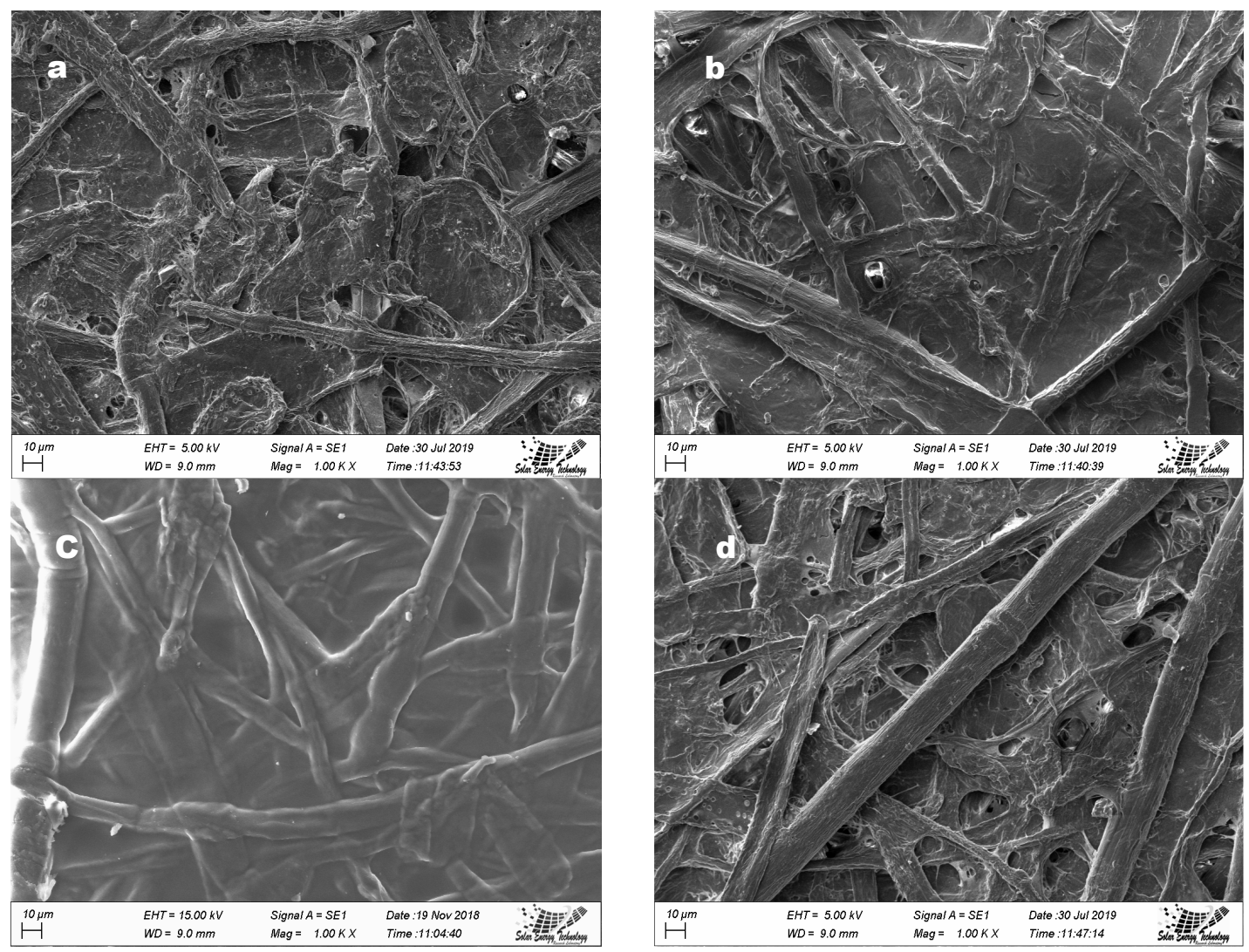

Figure 1: SEM images of coated paper; a) blank, b) coated with $1 \%$ chitosan, c) coated with $1 \%$ chitosan- $1 \%$ MCC and d) coated with $1 \%$ (1:1) chitosan-protein

\section{Barrier properties of coated paper}

The water-vapor transmission rate (WVTR) is the most important barrier property of packaging materials. To keep the food fresh and protect it against the growth of microorganisms, the WVTR of the packaging material needs to be improved. The coating barrier material should manifest resistance to polar water vapor, and be able to close as many pores and voids as possible, preventing the interaction between the polar groups of cellulosic fibers and water vapor. ${ }^{20}$ As shown in Figure 3, the water vapor permeability (WVTR) decreased with coating weight. The WVTR of paper coated with $1 \%$ chitosan decreased to $58.7 \mathrm{~g} / \mathrm{m}^{2}$ from $99.6 \mathrm{~g} / \mathrm{m}^{2}$, which further decreased to $35 \mathrm{~g} / \mathrm{m}^{2}$ with increasing chitosan concentration to $2 \%$. However, the paper 
coated with MCC-chitosan showed slightly higher WVPR at any coat weight.

The same decrease in WVTR was observed for the protein-chitosan coated paper, but the value was $16.1 \mathrm{~g} / \mathrm{m}^{2}$ higher than that of the chitosan coated paper. The result was, however, satisfactory, in comparison with that for uncoated paper. A similar effect of coating weight has been also reported after biopolymer coating due to clogging of the pores of the cellulose structure of paper achieved by the coating material. ${ }^{14}$

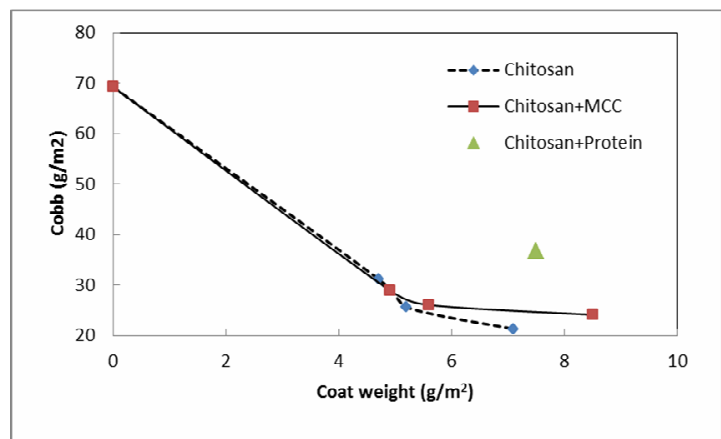

Figure 2: $\mathrm{Cobb}_{60}$ value of coated paper as a function of coat weight
Coating both sides of the paper with $2 \%$ chitosan and 3\% MCC reduced the WVTR to $48.5 \%$ (Table 4). Gatto et al. ${ }^{21}$ showed that the paper-film system involving chitosan with $2 \%$ degree of acetylation provided a better water barrier. Also, paper coating with nanofibrillated cellulose or nanofibrillated cellulose/chitosan nanoparticles has been reported to decrease the porosity and water absorption of paper. ${ }^{22}$ From the above discussion, it can be concluded that chitosan improved the WVPR of coated paper.

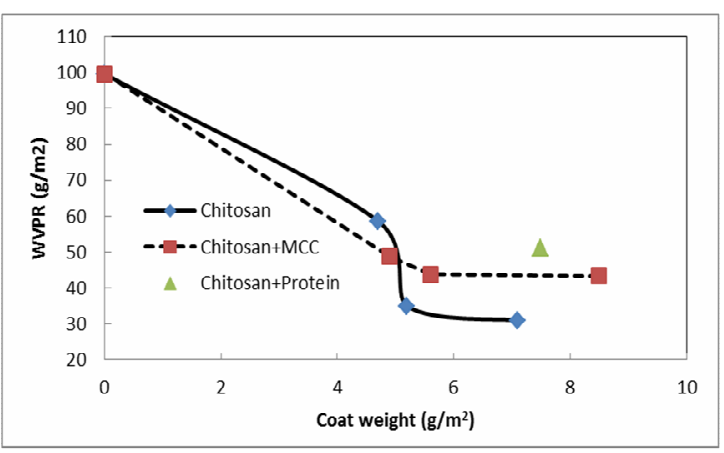

Figure 3: WVTR of coated paper as a function of coat weight

Table 3

Physical properties of coated paper

\begin{tabular}{ccccccc}
\hline Sr No & $\begin{array}{c}\text { Coat weight } \\
\left(\mathrm{g} / \mathrm{m}^{2}\right)\end{array}$ & \multicolumn{2}{c}{ Tensile index $(\mathrm{N} . \mathrm{m} / \mathrm{g})$} & Tear index $\left(\mathrm{mN} . \mathrm{m}^{2} / \mathrm{g}\right)$ & \multirow{2}{*}{$\begin{array}{c}\text { Burst index } \\
\left(\mathrm{kPa} . \mathrm{m}^{2} / \mathrm{g}\right)\end{array}$} \\
\cline { 2 - 5 } & 0 & 41.8 & 21.4 & $\mathrm{MD}$ & $\mathrm{CD}$ & 1.3 \\
2 & 4.7 & 42.8 & 22.8 & 4.5 & 6.2 & 1.8 \\
3 & 4.9 & 43.3 & 22.9 & 5.3 & 7.1 & 1.7 \\
4 & 5.6 & 42.8 & 22.7 & 5.3 & 7.0 & 1.8 \\
5 & 5.5 & 45.3 & 24.8 & 5.4 & 7.1 & 2.1 \\
6 & 5.2 & 43.8 & 23.3 & 5.4 & 7.3 & 1.8 \\
7 & 8.5 & 43.4 & 23.3 & 5.2 & 7.0 & 1.8 \\
8 & 8.8 & 45.2 & 23.3 & 5.0 & 7.0 & 2.0 \\
9 & 7.1 & 42.4 & 23.3 & 5.2 & 7.1 & 1.7 \\
10 & $7.5^{*}$ & 45.8 & 24.8 & 5.1 & 6.9 & 1.9 \\
\hline
\end{tabular}

Table 4

Paper surface properties for both sides coating

\begin{tabular}{cccccc}
\hline $\begin{array}{c}\text { Chitosan } \\
(\%)\end{array}$ & $\begin{array}{c}\text { MCC+ } \\
\text { protein }(\%)\end{array}$ & GSM & $\begin{array}{c}\text { Porosity } \\
(\mathrm{s})\end{array}$ & $\begin{array}{c}\text { Cobb }_{60} \\
\text { value }\end{array}$ & $\begin{array}{c}\text { WVTR } \\
\left(\mathrm{g} / \mathrm{m}^{2}\right)\end{array}$ \\
\hline 0 & 0 & 71.4 & 8 & 95.43 & 99.6 \\
2 & $1+0$ & 79.1 & 115 & 58.54 & 60.2 \\
2 & $3+0$ & 79.5 & 109 & 44.69 & 48.3 \\
2 & $5+0$ & 79.6 & 195 & 46.59 & 48.9 \\
2 & $3+1$ & 77.4 & 179 & 76.13 & 46.8 \\
2 & $3+2$ & 79.81 & 127 & 74.23 & 58.1 \\
2 & $3+3$ & 75.81 & 53 & 63.40 & 60.3 \\
\hline
\end{tabular}


Table 5

Papermaking properties for both sides coating

\begin{tabular}{ccccccc}
\hline \multirow{2}{*}{$\begin{array}{c}\text { Chitosan } \\
(\%)\end{array}$} & $\begin{array}{c}\text { MCC }+ \\
\text { protein }(\%)\end{array}$ & \multicolumn{2}{c}{ Tensile index $(\mathrm{N} . \mathrm{m} / \mathrm{g})$} & \multicolumn{2}{c}{ Tear index $\left(\mathrm{mN} . \mathrm{m}^{2} / \mathrm{g}\right)$} & \multirow{2}{*}{$\begin{array}{c}\text { Burst index } \\
\left(\mathrm{kPa} . \mathrm{m}^{2} / \mathrm{g}\right)\end{array}$} \\
\cline { 3 - 6 } & 0 & 41.8 & 21.4 & 4.5 & 6.24 & 1.3 \\
2 & $1+0$ & 42.2 & 23.3 & 5.3 & 5.41 & 1.9 \\
2 & $3+0$ & 43.5 & 23.3 & 5.3 & 6.83 & 2.0 \\
2 & $5+0$ & 42.5 & 23.3 & 5.4 & 6.62 & 2.0 \\
2 & $3+1$ & 45.8 & 24.8 & 5.0 & 6.84 & 2.1 \\
2 & $3+2$ & 45.9 & 24.3 & 5.1 & 6.14 & 1.6 \\
2 & $3+3$ & 45.8 & 24.7 & 6.0 & 7.05 & 1.7 \\
\hline
\end{tabular}

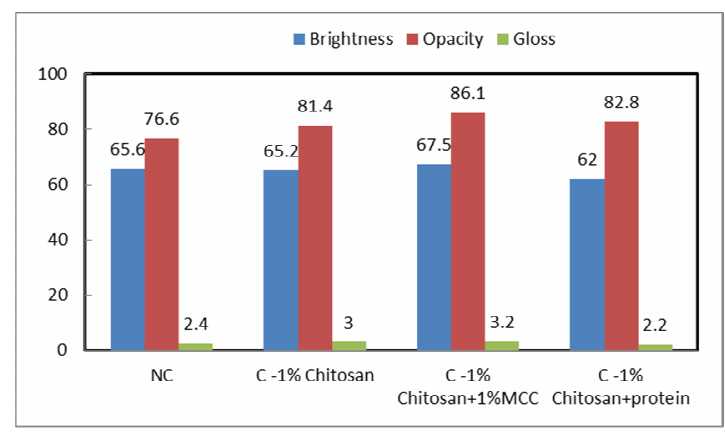

Figure 4: Opacity and brightness of coated paper

\section{Physical properties of coated paper}

The tensile, tear and burst indices of coated paper are important parameters for packaging paper. As shown in Table 3, the chitosan and chitosan-MCC coating improved slightly the papermaking properties. Coating with $1 \%$ chitosan increased by $3 \%$ the tensile index in MD, while the addition of $1 \% \mathrm{MCC}$ to the $1 \%$ chitosan solution increased the tensile index by $11 \%$. This result is partly attributed to the penetration of chitosan into the fiber network and also to the high compatibility between the chitosan and the cellulose fibers, resulting in the formation of a continuous film covering the fibers, which is evident in Figure 1. Similar results have been reported by other authors, i.e., a positive impact of coating paper with chitosan and water-soluble chitosan derivative on the mechanical properties of paper. ${ }^{2,10}$ In both MD and $\mathrm{CD}$, the highest tensile indexes were observed for the chitosanprotein coated paper. The tear index of coated paper increased more in CD than in MD. Gatto et $a l^{21}$ showed that the paper-film system involving chitosan with $2 \%$ degree of acetylation had improved mechanical resistance. In another study, it was observed that the strength of paper sheets was greatly increased by adding the dialdehyde chitosan/crosslinked amino starch composite to pulp, specifically, the tensile index and burst index of the paper sheets was increased by $31 \%$ and $35 \%$, respectively. ${ }^{23}$ Hassan et al. ${ }^{22}$ showed that the coating of paper sheets with a thin film of nanofibrillated cellulose or nanofibrillated cellulose/chitosan nanoparticles can improve the tensile strength properties of paper. Andze et al..$^{24}$ reported that the molecular chitosan additive also improved the tensile index of dry paper by approximately $15-25 \%$, the wet strength up to 9 times at $2.5 \%$ chitosan of the fiber weight. A combination of curdlan and chitosan also increased mechanical and water barrier properties. ${ }^{25}$

The physical properties of the paper coated on both sides are shown in Table 4 . The properties were almost similar to those of single side coated paper. Finally, it can be concluded that MCC reinforced and protein reinforced chitosan coating improved papermaking properties.

\section{Optical properties}

Chitosan coating has little influence on pulp brightness, but a significant effect on opacity. Paper coated with $1 \%$ chitosan had $4.8 \%$ higher opacity, which was further improved $(9.5 \%$ higher) with the addition of MCC to the chitosan solution. Higher opacity can be explained by an 
increase in light diffraction. As shown in Figure 4 , the brightness of paper coated with $1 \%$ chitosan and $1 \%$ MCC increased, while the brightness of paper coated only with chitosan decreased. The improved brightness provided by the MCC reinforced chitosan coating was mainly due to the brighter MCC that partly served as an optical additive. The loss of brightness in the chitosan only coated paper can be explained by the fact that the evaporation of acetic acid was more difficult in the presence of chitosan, as well as by the brownish color of chitosan. ${ }^{2}$ Lertsutthiwong $e t$ $a l .{ }^{26}$ also achieved similar results in using chitosan as a surface sizing agent.

Chitosan coating slightly increased the gloss (Fig. 4). The chitosan coatings were completely transparent and glossy, so their positive effect on the gloss values was expected. This phenomenon was also observed by Vartiainen et al. ${ }^{27}$

\section{CONCLUSION}

The functional properties of paper coated with chitosan, chitosan-MCC and chitosan-protein were investigated. Chitosan coating did not form a uniform film on the paper surface, but the diluted solution penetrates into the voids of paper, while chitosan simultaneously covers the fibers since cellulose and chitosan are chemically attracted due to hydrogen bonding. Papers coated with chitosan exhibited reduced water absorption, which was further reduced with the addition of MCC into chitosan coating solution. The WVTR of paper coated with $1 \%$ chitosan decreased to $58.7 \mathrm{~g} / \mathrm{m}^{2}$ from $71.1 \mathrm{~g} / \mathrm{m}^{2}$, which further decreased to $35 \mathrm{~g} / \mathrm{m}^{2}$ with increasing the chitosan concentration to $2 \%$. The chitosan and chitosanMCC coating improved slightly papermaking properties and significantly improved opacity. Paper coated with chitosan-protein did not improve the surface and barrier properties as much as the chitosan-MCC coating did.

ACKNOWLEDGEMENT: Authors wish to thank BCSIR for providing the necessary funds to carry out this research.

\section{REFERENCES}

1 H. Aloui, K. Khwaldia, M. B. Slama and M. Hamdi, Carbohyd. Polym., 86, 1063 (2011), https://doi.org/10.1016/j.carbpol.2011.06.026

2 S. C. Fernandes, C. S. Freire, A. J. Silvestre, J. Desbrieres, A. Gandini et al., Ind. Eng. Chem. Res., 49, 6432 (2010), https://doi.org/10.1021/ie100573z
3 S. Habibie, M. Hamzah, M. Anggaravidya and E. Kalembang, J. Chem. Eng. Mater. Sci., 7, 1 (2016), https://doi.org/10.5897/JCEMS2015.0235

4 S. Kopacic, A. Walzl, A. Zankel, E. Leitner and W. Bauer, Coatings, $\quad \mathbf{8 ,} 235 \quad$ (2018), https://doi.org/10.3390/coatings 8070235

5 C. Andersson, Packag. Technol. Sci., 21, 339 (2008), https://doi.org/10.1002/pts.823

M.-B. Coltelli, F. Wild, E. Bugnicourt, P. Cinelli, M. Lindner et al., Coatings, 6, 1 (2016), https://doi.org/10.3390/coatings6010001

7 C. Johansson, J. Bras, I. Mondragon, P. Nechita, D. Plackett et al., Bioresources, 7, 2506 (2012), https://ojs.cnr.ncsu.edu/index.php/BioRes/article/view/ 2438

8 M. Gällstedt and M. S. Hedenqvist, J. Polym. Environ., $\quad \mathbf{1 0}, 12002$, https://doi.org/10.1023/A:1021068304169

9 M. Gällstedt, A. Brottman and M. S. Hedenqvist, Packag. Technol. Sci., 18, 161 (2005), https://doi.org/10.1002/pts.685

10 J. Kuusipalo, M. Kaunisto, A. Laine and M. Kellomaki, Tappi J., 4, 17 (2005), http://tappi.org/

11 M. S. Jahan, A. Noori, L. Ahsan and D. A. N. Chowdhury, IPPTA J., $2, \quad 85 \quad$ (2009), https://ippta.co/eLibraryNew/2009/2009_Issue_2_IPP TA_Articel_07.pdf

12 W. Zhang, H. Xiao and L. Qian, Carbohyd. Polym., 101, 401 (2014), https://doi.org/10.1016/j.carbpol.2013.09.097

13 H. Kjellgren, M. Gallstedt, G. Engstrom and L. Jarnstrom, Carbohyd. Polym., 65, 453 (2006), https://doi.org/10.1016/j.carbpol.2006.02.005

14 K. Khwaldia, A. H. Basta, H. Aloui and H. ElSaied, Carbohyd. Polym., 99, 508 (2014), https://doi.org/10.1016/j.carbpol.2013.08.086

15 S. M. Mousavi, E. Afra, M. Tajvidi, D. W. Bousfield and M. Dehghani-Firouzabadi, Cellulose, 24, 3001 (2017), https://doi.org/10.1007/s10570-0171299-5

16 F. Nessa, S. M. Masum, M. Asaduzzaman, S. K. Roy, M. M. Hossain et al., Bangladesh J. Sci. Ind. Res., $\quad 45, \quad 323 \quad$ (2010), https://doi.org/10.3329/bjsir.v45i4.7330

17 M. Nuruddin, A. Chowdhury, S. A. Haque, M. M. Rahman, S. F. Farhad et al., Cellulose Chem. Technol., 45, 347

(2011),

http://www.cellulosechemtechnol.ro/pdf/CCT45,56(2011)/p.347-354.pdf

18 S. Wang and Y. Jing, Appl. Clay Sci., 138, 74 (2017), https://doi.org/10.1016/j.clay.2016.12.037

19 S. Kopacic, A. Walzl, A. Zankel, E. Leitner and W. Bauer, Coatings, $\quad \mathbf{8 ,} 235 \quad$ (2018), https://doi.org/10.3390/coatings8070235

20 L. Nilsson, B. Wilhelmsson and S. Stenstrom, Dry. Technol. 11, $\quad 1205$ (1993), https://doi.org/10.1080/07373939308916896 


\section{TAWHIDA AKTER et al.}

21 M. Gatto, D. Ochi, C. M. P. Yoshida and C. F. da Silva, Carbohyd. Polym., 210, 56 (2019), https://doi.org/10.1016/j.carbpol.2019.01.053

22 E. A. Hassan, M. L. Hassan, R. E. Abou-Zeid and N. A. El-Wakil, Ind. Crop. Prod., 93, 219 (2016), https://doi.org/10.1016/j.indcrop.2015.12.006

23 M. Wu, W. Lv, F. Wang, Z. Long, J. Chen and C. Dong, Cellulose Chem. Technol., 52, 43 (2018), http://www.cellulosechemtechnol.ro/pdf/CCT12(2018)/p.43-49.pdf

24 L. Andze, J. Zoldners, L. Rozenberga, I. Sable, M. Skute et al., Cellulose Chem. Technol., 52, 873 (2018),
http://www.cellulosechemtechnol.ro/pdf/CCT910(2018)/p.873-881.pdf

25 U. V. Brodnjak, Progress Org. Coatings, 112, 86 (2017), https://doi.org/10.1016/j.porgcoat.2017.06.030

26 P. Lertsutthiwong, M. M. Nazhad, S. Chandrkrachang and W. F. Stevens, Appita J., 57, 274 (2004)

27 J. Vartiainen, R. Motion, H. Kulonen, M. Rättö, E. Skyttä et al., J. Appl. Polym. Sci., 94, 986 (2004), https://doi.org/10.1002/app.20701 